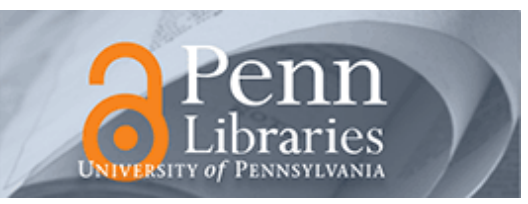

University of Pennsylvania

ScholarlyCommons

$9-1-2005$

\title{
The Relationship Between Parental Involvement as Social Capital and College Enrollment: An Examination of Racial/Ethnic Group Differences
}

\author{
Laura W. Perna \\ University of Pennsylvania, Iperna@gse.upenn.edu \\ Marvin A. Titus \\ North Carolina State University
}

Follow this and additional works at: https://repository.upenn.edu/gse_pubs

Part of the Education Commons

\section{Recommended Citation}

Perna, L. W., \& Titus, M. A. (2005). The Relationship Between Parental Involvement as Social Capital and College Enrollment: An Examination of Racial/Ethnic Group Differences. Retrieved from

https://repository.upenn.edu/gse_pubs/14

Copyright The Ohio State University. Reprinted from Journal of Higher Education, Volume 76, Issue 5, September/ October 2005, pages 485-518. This material is posted here with the permission of the Ohio State University Press. Content may not be copied or emailed to multiple sites or posted to a listserv or website without the copyright holder's written permission. However, users may print, download, or email articles for individual use.

Note: At the time of publication, Laura W. Perna was affiliated with the University of Maryland, College Park. Currently (August 2006), she is a faculty member at the Graduate School of Education at the University of Pennsylvania.

This paper is posted at ScholarlyCommons. https://repository.upenn.edu/gse_pubs/14

For more information, please contact repository@pobox.upenn.edu. 


\title{
The Relationship Between Parental Involvement as Social Capital and College Enrollment: An Examination of Racial/Ethnic Group Differences
}

\author{
Abstract \\ Although comparable percentages of African American and White high school sophomores expect to \\ finish college (Nettles \& Perna, 1997), smaller shares of African Americans and Hispanics than of Whites \\ actually enroll. Only $39 \%$ of African American and $32 \%$ of Hispanic high school graduates between the \\ ages of 18 and 24 were addenrolled in college in 1999, compared with $45 \%$ of Whites (National Center for \\ Education Statistics [NCES], 2001). \\ Disciplines \\ Education

\section{Comments} \\ Copyright The Ohio State University. Reprinted from Journal of Higher Education, Volume 76, Issue 5, \\ September/October 2005, pages 485-518. This material is posted here with the permission of the Ohio \\ State University Press. Content may not be copied or emailed to multiple sites or posted to a listserv or \\ website without the copyright holder's written permission. However, users may print, download, or email \\ articles for individual use. \\ Note: At the time of publication, Laura W. Perna was affiliated with the University of Maryland, College \\ Park. Currently (August 2006), she is a faculty member at the Graduate School of Education at the \\ University of Pennsylvania.
}




\section{fE Laura Walter Perna \\ Marvin A. Titus}

\section{The Relationship between Parental Involvement as Social Capital and College Enrollment: An Examination of Racial/Ethnic Group Differences}

Although comparable percentages of African American and White high school sophomores expect to finish college (Nettles \& Perna, 1997), smaller shares of African Americans and Hispanics than of Whites actually enroll. Only 39\% of African American and $32 \%$ of Hispanic high school graduates between the ages of 18 and 24 were enrolled in college in 1999, compared with $45 \%$ of Whites (National Center for Education Statistics [NCES], 2001).

College preparation programs (also known as early intervention programs and pre-collegiate outreach programs) are an increasingly common approach to raising the college enrollment rates of African Americans, Hispanics, and other groups of students who are underrepresented in higher education. Although the federal government has been involved with college preparation programs since the establishment of the TRIO programs in the 1960s, the federal government extended its role in 1998 with the establishment of GEAR-UP (Gaining Early Awareness and Readiness through Undergraduate Preparation). State governments, notfor-profit organizations, and individual colleges and universities also

Laura W. Perna is Assistant Professor of Higher Education at the University of Maryland, College Park. Her research explores the individual and structural factors that limit the ability of women, racial/ethnic minorities, and individuals of lower socioeconomic status to realize the economic, political, and social opportunities that are associated with two aspects of higher education: access as a student and employment as a faculty member. Marvin A. Titus is Assistant Professor of Higher Education at North Carolina State University, Raleigh. His research interests include college student access, persistence, labor market outcomes, and higher education finance.

The Journal of Higher Education, Vol. 76, No. 5 (September/October 2005)

Copyright () 2005 by The Ohio State University 
sponsor college preparation programs (Fenske, Geranios, Keller, \& Moore, 1997). These programs are designed to promote educational attainment among disadvantaged groups of students by developing the skills, knowledge, confidence, aspirations, and preparation that are needed to enroll in and graduate from college.

Administrators of college preparation programs, as well as researchers and policy analysts, generally believe that "parental involvement" is a component of "successful" programs (Swail \& Perna, 2000; Tierney, 2002). A 1999 survey by the College Board revealed that more than two thirds $(70 \%)$ of college preparation programs that target historically underrepresented minority groups report having a parental involvement component; for one third of all programs, parents of participating students are required to participate (Perna, 2002). Despite this high self-reported prevalence, however, some research (Tierney, 2002) suggests that parents are only superficially involved, likely because these programs often lack the time, funding, staffing, and other resources that are required for more substantial involvement.

The stated commitment of most college preparation programs to involve parents reflects an assumption that parental involvement promotes the college enrollment of underrepresented groups of students. Researchers have found that parental involvement is associated with a greater likelihood of aspiring to attend college and actually enrolling (Cabrera \& La Nasa, 2000; Horn, 1998; Hossler, Braxton \& Coopersmith, 1989; Hossler, Schmit \& Vesper, 1999; Perna, 2000), as well as with higher grades (Lee, 1993; Muller, 1993; Zick, Bryant, \& Osterbacka, 2001), higher eighth grade mathematics and reading achievement (Lee, 1993; Sui-Chu \& Willms, 1996), lower rates of behavioral problems (Lee, 1993; Zick, Bryant, \& Osterbacka, 2001), and lower likelihood of high school dropout and truancy (McNeal, 1999).

Nonetheless, research on the relationship between parental involvement and college enrollment is limited in several ways. When included in quantitative analyses, parental involvement is generally operationalized using just one indicator such as a composite of the frequency of discussions between the parent and child about school-related activities (e.g., Horn, 1998; Perna, 2000), rather than a multidimensional construct as recommended by some researchers (e.g., Sui-Chu \& Willms, 1996). The role of parental involvement in college enrollment is also generally conceptualized as an individual-level characteristic with no attention to the structural constraints that influence involvement or the types of resources that may be accessed through such involvement (Horvat, 2001). Moreover, although some researchers (Perna, 2000; St. John, 1991) have shown that the college enrollment process varies across racial/ethnic groups, other researchers (Dika \& Singh, 2002; Mattingly, 
Prislin, McKenzie, Rodriguez, \& Kayzar, 2002; McNeal, 1999; Tierney \& Auerbach, in press) have concluded that little is known about the extent to which the relationship between parental involvement and college enrollment varies by race/ethnicity.

Although some research (Perna, 2002; Swail \& Perna, 2000) has described the characteristics and components of college preparation programs, few studies have examined the effectiveness of those programs in general or of such components as parental involvement in particular (Tierney, 2002). While this study does not address the need for methodologically and analytically rigorous evaluations of the parental involvement components of particular college preparation programs, this study sheds light on the ways in which parental involvement influences the college enrollment of African Americans and Hispanics more generally. The results suggest that allocating resources to promote parental involvement is an effective approach for programs that are designed to increase the college enrollment of underrepresented groups.

To examine the relationship between parental involvement and college enrollment, this study draws on the work of Bourdieu (1986), Coleman (1988), and Lin (2001a, 2001b) to conceptualize parental involvement as a form of social capital that provides individuals with access to resources that may facilitate college enrollment. The conceptual model recognizes, as Bourdieu (1986) and Lin (2001b) suggest, that an individual's action (e.g., college enrollment) cannot be fully understood except in terms of the structural context. The structural context is defined in terms of the characteristics of the high school attended: specifically, the extent to which the school encourages parental involvement, the volume of resources that may be accessed via social networks at the school, and the homogeneity of the social networks at the school. As suggested by the underlying theoretical perspectives, the multilevel multinomial analyses show that the likelihood of enrolling in a 2-year or 4-year college depends not only on an individual student's parental involvement but also on the volume of social and other forms of capital that may be accessed via social networks at the school. The analyses also show that the relationship between college enrollment and parental involvement is different for African Americans than for other high school graduates. This article concludes by discussing the implications of these findings for college preparation programs.

\section{Conceptual Framework: Parental Involvement as a Form of Social Capital}

This study integrates aspects of Coleman (1988), Bourdieu (1986), and Lin (2001a, 2001b) into a comprehensive conceptual model for understanding the relationship between parental involvement, as a form of 
social capital, and college enrollment. Like other forms of capital, social capital is a resource that students may draw upon as needed to enhance productivity (Coleman, 1988), facilitate upward mobility (DiMaggio \& Mohr, 1985; Lamont \& Lareau, 1988), and realize economic returns (Lin, 2001b). A primary function of social capital is to enable a student to gain access to human, cultural, and other forms of capital, as well as to institutional resources and support (Coleman, 1988; Hofferth, Boisjoly, \& Duncan, 1998; Lin, 2001b; Morrow, 1999; Portes, 1998; Stanton-Salazar \& Dornbusch, 1995).

Researchers have used varying conceptualizations of social capital (Dika \& Singh, 2002; Horvat, Weininger, \& Lareau, 2003; Portes, 1998) and, in some instances, as McNeal (1999) notes, have blurred the distinctions between social capital and cultural capital. Cultural capital refers to the system of attributes, such as language skills, cultural knowledge, and mannerisms, that is derived in part from one's parents and that defines an individual's class status (Bourdieu, 1986; Bourdieu \& Passeron, 1977). Middle- and upper-class individuals possess the most valued forms of cultural capital (McDonough, 1997). Social capital focuses on social networks and the ways in which social networks and connections are sustained (Morrow, 1999). In his comprehensive assessment of the origins and uses of social capital, Portes (1998) noted that social capital is acquired through an individual's relationships with other individuals, particularly through membership in social networks and other social structures.

Coleman (1988) and Bourdieu (1986) offer two somewhat different conceptualizations of social capital. Coleman's (1988) approach, the approach most frequently used in educational research (Dika \& Singh, 2002), stresses the role of social capital in communicating the norms, trust, authority, and social controls that an individual must understand and adopt in order to succeed. Coleman identifies the ways in which parental involvement can build social capital (Dika \& Singh, 2002), suggesting that social capital is derived from two types of relationships: the relationship between a student and his/her parents; and relationships between a student's parents and other adults, particularly adults who are connected to the school that the student attends.

Bourdieu focuses on the ways in which some individuals are advantaged because of their membership in particular groups (Portes, 1998). According to Bourdieu (1986), the amount of social capital to which an individual may gain access through social networks and relationships depends on the size of the networks as well as on the amounts of economic, cultural, and social capital that individuals in the network possess. Bourdieu views social capital as a mechanism that the dominant class uses to maintain its dominant position (Lin, 2001b). 
While Coleman's perspective suggests that parents play a primary role in promoting the status attainment of their children, Bourdieu's approach describes the restrictions that structural barriers, in the form of differential access across racial/ethnic, gender, and other groups, to institutional resources impose (Dika \& Singh, 2002). Despite this and other differences (Dika \& Singh, 2002; Lin, 2001b), both Coleman and Bourdieu recognize that "social capital consists of resources embedded in social relations and social structures, which can be mobilized when an actor wishes to increase the likelihood of success in a purposive action" (Lin, 2001b, p. 24).

Drawing on the work of Coleman and Bourdieu, Lin (2001b) developed a theory of social capital that focuses on the mechanisms and processes through which an individual obtains the resources that are embedded in social networks. Coleman (1988) argues that network closure (i.e., "intergenerational closure") promotes effective communication and enforcement of social norms as well as shared expectations, goals, and values. Bourdieu also suggests that network closure is required for the dominant class to preserve its dominant position (Lin, 2001a). In contrast, Lin (2001a, 2001b) asserts that network closure is not required. Lin suggests that, whereas closed networks, or strong ties, may effectively preserve resources, weak ties may enable an individual to access resources that are not available via strong ties. In other words, weak ties may serve as a "bridge" to networks that possess information and resources that are different from those that are provided by strong ties or by an individual's family and close friends (Granovetter, 1983; Lin, 2001b). Lin assumes that, although individuals generally establish relationships with individuals who have similar perspectives and socioeconomic backgrounds (i.e., the homophilous principle), some individuals seek relationships with individuals who are of a somewhat "better" social status in order to gain additional resources (i.e., the heterophilous principle).

Research suggests that both strong and weak ties may play a role in educational outcomes. Using longitudinal data from the National Educational Longitudinal Study (NELS), Carbonaro (1998) found that the chances of a child dropping out of high school declined as the number of the child's friends' parents with whom a parent reported talking (i.e., strong ties) increased, after controlling for background characteristics, parental expectations, and such measures of behavior as skipping school, suspensions, and number of friends who had dropped out. Using longitudinal data from the Panel Study of Income Dynamics, Hofferth et al. (1998) found that weak ties, defined as parents' access in an emergency to financial and other assistance from friends, were positively 
related to college attendance for students from high-income families, whereas strong ties, defined as parents' access in an emergency to financial and other assistance from relatives, were unrelated to college attendance regardless of family income.

\section{Structural Constraints and Resources: The Role of the School Context}

Both Bourdieu (Bourdieu \& Wacquant, 1992) and Lin (2001b) argue that an individual's actions cannot be fully understood except in relation to the social context in which those actions occur. Bourdieu's notion of habitus describes the ways in which individual actions and societal structures are linked. Habitus is the internalized set of dispositions and preferences that subconsciously define an individual's reasonable actions (Bourdieu \& Wacquant, 1992; Horvat, 2001; McDonough, 1997). The habitus reflects the internalization of structural boundaries and constraints and determines what is possible for an individual (Horvat, 2001).

Structural characteristics of the school may restrict college enrollment through their influence on social networks and relationships (StantonSalazar, 1997). Stanton-Salazar argues that such institutional agents as teachers, counselors, and middle-class peers provide access to resources and opportunities including information about college and help with college-admissions requirements but that institutional structures limit the ability of working-class minority students to develop "trusting" relationships with institutional agents. Among the structures that may restrict the growth of social capital for working-class minority students are the focus of schools on bureaucratic processes, the dual role of teachers and counselors as mentors and gatekeepers, and the short-term duration of interactions (Stanton-Salazar, 1997).

\section{Variations across Racial/Ethnic Groups in the Conversion of Social Capital}

Although some research suggests variations by family income in the conversion of social capital into college enrollment (Hofferth et al., 1998), little is known about racial/ethnic group differences in the ways in which parental involvement as a form of social capital promotes college enrollment. In addition to the need to understand the causes of observed racial/ethnic group gaps in college enrollment, attention to this issue is warranted for at least four reasons.

First, research shows that the relationship between parental involvement and other outcomes varies across racial/ethnic groups. Using data from the NELS, McNeal (1999) found that, after controlling for other 
variables, the positive effects of parental involvement on reducing the likelihood of high school dropout and truancy were smaller for Blacks, Hispanics, and Asian Americans than for Whites. Also using data from the NELS, Qian and Blair (1999) showed that parental involvement was a predictor of educational aspirations for African American, Hispanic, and White high school seniors, but not for Asian American high school seniors, after controlling for individual characteristics, financial capital, and human capital.

Second, as López, Scribner, and Mahitivanichcha (2001) observed, most approaches to parental involvement rely on a cultural deficit approach that emphasizes traditional forms of parental involvement without considering the ways in which the nature of parental involvement may vary across groups. In their qualitative study of four school districts with large migrant populations, López and colleagues (2001) found that, before parents could participate in their child's education in a meaningful way, their social, economic, and physical needs had to be addressed. Successfully involving parents required recognizing the cultural and educational strengths, as well as the economic and structural barriers, of the migrant families (López et al., 2001).

Third, a Bourdieuian approach predicts that the relationship between parental involvement as social capital and college enrollment will vary across racial/ethnic groups, as Bourdieu argues that barriers based on race/ethnicity as well as those based on sex and class restrict access to institutional resources (Dika \& Singh, 2002). Thus, a student's interpretation of acceptable actions, or habitus, will vary, at least in part, based on his/her race (Horvat, 2001). Consistent with this perspective, Freeman's (1997) qualitative study of the perceived barriers to the college enrollment of African Americans suggests that many African American students are not encouraged to pursue college by their parents or other adults.

Finally, Lin's (2001b) theory of social capital suggests that racial/ethnic group variations in college enrollment are attributable, at least in part, to racial/ethnic group differences in the types of resources that are available through a school's social networks. Lin assumes that social structures have a pyramidal shape in which the degree of access to and control over resources is positively related to an individual's position or level within the social hierarchy. Thus, groups that are disadvantaged relative to other groups in terms of their social positions (e.g., African Americans and Hispanics relative to Whites) may also be disadvantaged in terms of their access to valued resources. This perspective predicts that, in order to compensate for their relatively disadvantaged positions, African Americans and Hispanics are more likely than Whites are to rely on heterophilous interactions and weak ties as a source of resources that 
promote college enrollment (Lin, 2001b). This hypothesis is consistent with work by Fries-Britt (1998) on high-ability Black students. Her qualitative research suggests that high-achieving Black students generally have few opportunities to establish relationships with other highachieving Black students during high school regardless of the racial/ethnic composition of the high school. Thus, Lin's perspective suggests that variations across schools in the resources possessed by social networks and the extent to which heterophilous interactions are possible may be a source of racial/ethnic differences in college enrollment across schools.

\section{Research Method}

Drawing on the work of Coleman (1988), Bourdieu (1986; Bourdieu \& Wacquant, 1992), and Lin (2001b), this study uses the multinomial extension of hierarchical linear modeling (HLM) to address the following research questions:

1. What is the relationship between parental involvement, a studentlevel form of social capital, and the likelihood that a student enrolls in a 2-year or 4-year college or university in the fall after graduating from high school after controlling for other studentlevel predictors of college enrollment and school-level structural characteristics?

2. How does the relationship between different types of parental involvement and the likelihood of enrolling in a 2-year or 4-year college or university vary across racial/ethnic groups after controlling for other student- and school-level variables?

3. What is the relationship between the characteristics of the social networks at the school attended and the likelihood that a student enrolls in a 2-year or 4-year college or university after controlling for student-level predictors?

\section{Sample}

Data from the second (1992) and third (1994) follow-ups to the NELS were used to examine the research questions. Sponsored by the U.S. Department of Education's National Center for Education Statistics, the NELS contains data for a cohort of students in the eighth grade (1988), when they are high school sophomores (1990), when they are high school seniors (1992), and when they are two years out of high school (1994). The sample is limited to individuals who graduated from high school as scheduled in 1992. 
The sample excludes American Indians/Alaskan Natives $(n=128)$ and students of unknown $(n=3)$ race/ethnicity because of their small numbers. The sample also excludes 1,421 cases that are missing high school identification numbers. As recommended by Snijders and Bosker (1999), the analyses exclude 245 students who are the sole representative of their high school since variances and other statistics cannot be calculated for groups with only one case. The analytic sample numbers 9,810 high school graduates attending 1,006 high schools.

\section{Conceptual Model}

Figure 1 summarizes the conceptual model that was used to address the research questions. The model shows that both student-level characteristics, including the amounts of different types of capital that an individual student possesses and structural characteristics of the school that a student attends, influence college enrollment. Although the focus of this study was on the contribution of parental involvement as social capital, the conceptual model recognizes that other forms of capitalnamely economic, cultural, and human capital-reflect aspects of an individual's habitus and thus influence college enrollment decisions. The dependent variable, college enrollment, was measured in October 1992, the fall after the student's scheduled graduation from high school. The variable has three categories: enrolled in a 2-year college; enrolled in a 4-year college or university; and not enrolled (reference category). Appendices $\mathrm{A}$ and $\mathrm{B}$ provide operational definitions for the student- and school-level variables in the analyses.

\section{Student-Level Variables}

At the student level, the analyses control for race/ethnicity, gender (female, yes or no), and several forms of capital. The analyses include four racial/ethnic groups: African American, Asian, Hispanic, and White (reference group).

Economic capital is measured by variables that reflect an individual's actual and perceived ability to pay the costs of college (Paulsen \& St. John, 2002). Family income in 1991, a measure of actual ability to pay, is a 15-category variable ranging from no income to more than $\$ 200,000$. Following the example of Paulsen and St. John (2002), perceived ability to pay "fixed" college costs is measured by whether a student reports that neither college expenses nor financial aid is important in the choice of college, both college expenses and financial aid are very important, or college expenses and financial aid are somewhat important 


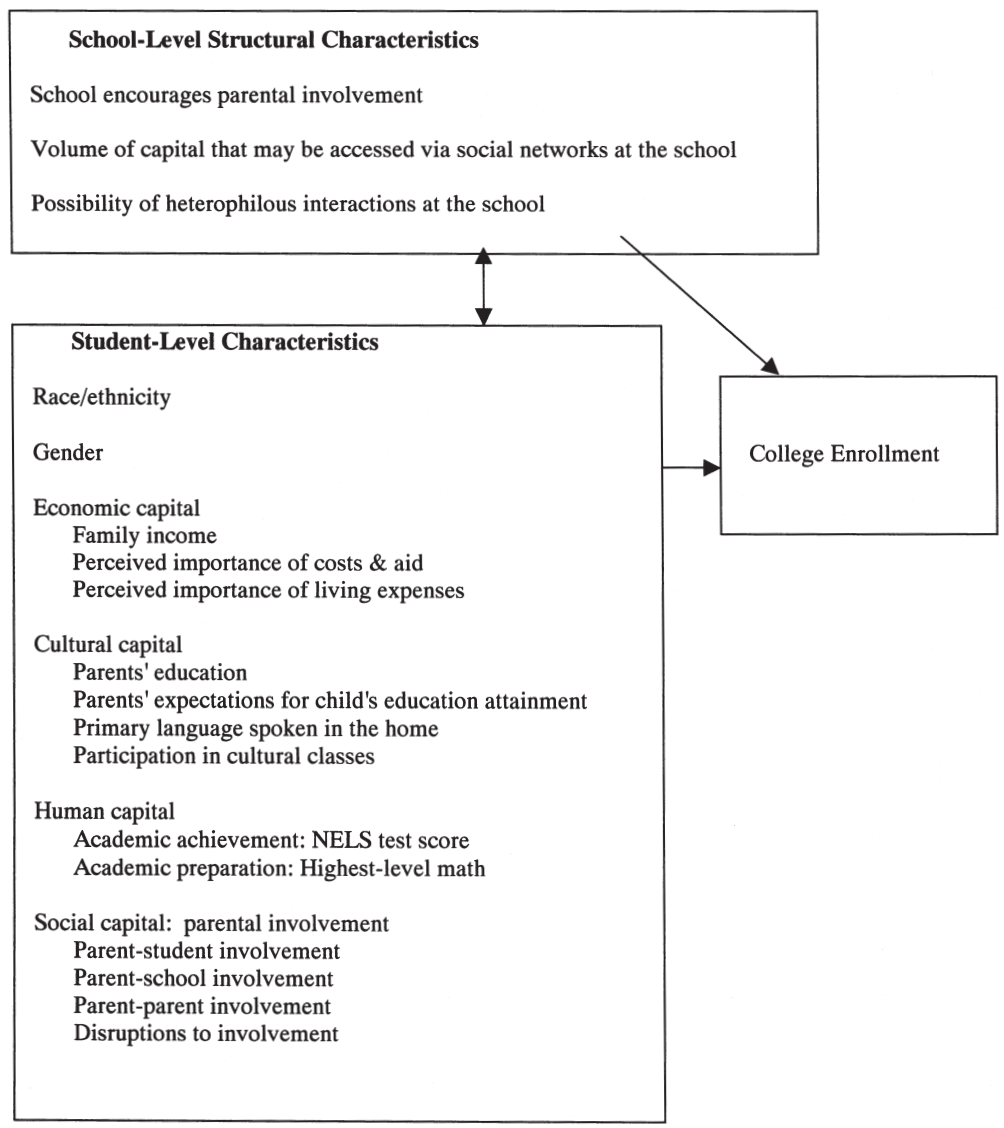

FIG. 1. Conceptual Model of College Enrollment

(reference category). Perceived ability to pay "controllable" costs is measured by whether a student reports that living at home to attend college is very important to the college choice.

Cultural capital is measured by four variables that are designed to reflect an individual's language skills, cultural knowledge, values about higher education, and class status. One measure is parents' educational attainment, defined as the highest level of education that either parent has attained. A second measure reflects the highest level of education that parents report that they expect their child to attain: less than a college degree, a college degree, or an advanced degree (reference category). The third measure reflects whether English is the primary language that is spoken in the student's home. Following the example of Downey and Powell (1993), cultural capital is also measured by whether a student reports taking music, art, or dance classes at least once a week. 
Human capital is measured by academic achievement and academic preparation. Academic achievement is measured by the standardized composite score on the reading and mathematics tests that were administered as part of the NELS data collection in 1992. Test scores are used rather than grades because grades are more likely than test scores to reflect differences in standards, expectations, and behaviors across schools (Muller, 1993).

Although positively related to college enrollment, academic curricular track is an unreliable measure of academic preparation (Adelman, 1999; Stevenson, Schiller, \& Schneider, 1994). Adelman (1999) suggests that a better measure of the quality and intensity of academic preparation is the highest level of coursework that is completed in particular subjects. Because the hierarchical sequence of courses is clearer for mathematics than for other subjects, this research, like other research (e.g., Horn, 1998), measures the quality of academic preparation by the highest level of mathematics coursework that was completed at the time of high school completion. A series of dichotomous variables reflects the highest level of mathematics that a student completed: algebra I and geometry; algebra II; or at least one advanced math course. Other or no mathematics coursework is the reference category.

Social capital as measured by parental involvement. Using Coleman's (1988) conceptualization, parental involvement is a form of social capital that may promote college enrollment because of the relationship between a student and her/his parents, the relationship between the student's parents and school officials, and the relationship between the student's parents and the student's friends' parents.

Parent-student involvement is measured by parent-student discussions about education-related issues and by parental monitoring of the student's behavior. Parent-student discussions about education-related issues is a factor composite ${ }^{1}$ that is comprised of six parent-reported variables that reflect the frequency of discussions regarding the student's selection of courses, school activities, topics studied in schoolwork, grades, plans to take the SAT or ACT, and applications to college. The alpha reliability coefficient for this composite is 0.80 . The second factor composite, parental monitoring, reflects whether, as reported by the parent, the family has rules about maintaining a minimum grade point average, doing homework, and attending school regularly. The alpha reliability coefficient for this composite is 0.79 .

Parent-school involvement is measured by one single-item measure and four factor composites. The single questionnaire item measures the frequency with which the parent reports contacting the student's school about doing volunteer work. The first factor-parent acts to acquire 
information about college-reflects whether the parent reports attending a program about educational opportunities after high school, a program about college financial aid, or both. The second factor-parent knows about academic requirements - reflects whether the parent reports knowing which courses the student is taking, how well the student is doing in school, the number of credits the student has earned toward high school graduation, and the number of credits that is required to graduate from high school. The third factor-parent initiates contact with the school about academic issues-reflects the extent to which the parent reports contacting the school about academic performance, academic program, plans after high school, and college preparatory course selection. The fourth factor-parent initiates contact with the school about behavioral problems - reflects the frequency with which the parent reports contacting the school about the student's attendance or behavior. The alpha reliability coefficients for these four factors are 0.76 , $0.78,0.79$, and 0.59 , respectively.

Parent-to-parent involvement, an indicator of intergenerational closure, is measured by the number of the student's friends' parents with whom a parent reports talking. The postsecondary plans of a student's friends may provide an additional measure of intergenerational closure or may reflect the subtle ways in which parents structure a student's activities to influence the composition of the peer group (Tierney \& Auerbach, in press). Peer plans are measured by the share of a student's friends who plan to attend a 4-year college, 2-year college, or no college after graduating from high school.

By interrupting a parent's relationships with other parents as well as with school officials, geographic mobility may disrupt social capital (Hofferth et al., 1998). To account for possible disruptions to social capital, the analyses include a variable measuring the number of times that a student's family moved between 1988 and 1992.

\section{School-level variables}

The conceptual model incorporates Bourdieu's (1986) and Lin's (2001a, 2001b) assumptions that an individual's behavior cannot be understood except in terms of the social context in which the behavior occurs and that the social capital to which an individual may gain access through social networks depends on the volume of economic, cultural, and social capital that individuals in the network possess. Figure 1 shows that the conceptual model includes structural characteristics that reflect three aspects of the social networks at the school attended: the extent to which the school encourages parental involvement, the volume 
of resources that may be accessed via social networks at the school, and the extent to which heterophilous interactions may occur at the school. The extent to which a school encourages parental involvement is measured by a factor composite of eight variables that are reported by school administrators. The factor composite is comprised of the extent to which the school reports that parents are involved with establishing curricular guidelines, grading and student evaluation policies, discipline policies, textbooks and materials, course offerings, school expenditure priorities, policies for grouping student classes, and criteria for hiring and firing teachers. The alpha reliability coefficient for the factor is 0.81 .

Other school-level measures that may reflect both the extent of school encouragement for parental involvement and the volume of social capital in the form of parental involvement that is available through social networks at the school are the school-reported percentages of parents who volunteer time in the classroom and who participate in a parent-teacher organization. The volume of social capital that is available through social networks is also measured by the average of each of the student-level measures of parental involvement (e.g., average frequency of parent-student discussions about education-related issues) at the school attended.

The volume of economic, cultural, and human capital that is available through social networks at the school is measured by school-level averages of the following student-level variables: family income, parental education, parental educational expectations, and test scores. The percentages of the prior year's (1991) 12th graders who enrolled in 2-year and 4-year colleges are additional measures of the cultural capital that is available through school social networks.

The extent to which heterophilous interactions, or weak ties, may provide access to otherwise unavailable resources is measured by the standard deviation of the family income of students attending the same school and the percentages of African Americans and Hispanics in the school student body. These three variables provide an indication of the diversity of the students attending a school in terms of family income and race/ethnicity.

\section{Missing Data}

Data are not missing randomly for several of the student-level variables in the model. Following the recommendation by Cohen and Cohen (1983), the student-level analyses include a single independent variable that reflects the "tendency to have missing data." This variable is calculated as the number of independent variables on which data are missing. Mean scores for the cases missing data on each of the continuous independent variables are imputed. 
Analyses

HLM is used to address the research questions. Because the dependent variable has three categories, the analyses use the multinomial extension of HLM (Raudenbush \& Bryk, 2002).

HLM is appropriate for at least four reasons. First, to address the research questions, the relationship between college enrollment and an individual student's parental involvement must be isolated from the relationship between college enrollment and the school-level characteristics of the social networks that may be accessed through such involvement. Testing hypotheses about the relationship between variables at two levels is one of the primary uses of HLM (Bryk \& Raudenbush, 1992).

Second, preliminary analyses suggest that differences in school characteristics are a source of observed differences in college enrollment. A one-way ANOVA of an unconditional model shows that $13 \%$ of the variance in college enrollment is accounted for by differences in the characteristics of the schools that students attend.

Third, unlike other statistical methods, HLM allows for an examination of whether structural relations vary across schools. This feature is used to examine the third research question, which focuses on the relationship between school characteristics and college enrollment.

Finally, HLM is appropriate for statistical reasons. Failing to account statistically for different units of analysis (i.e., student and school) can lead to aggregation bias, miscalculation of standard errors, and heterogeneity of regression (Bryk \& Raudenbush, 1992). HLM also addresses the design effects that are inherent in the NELS dataset, which utilized a sampling frame that first sampled schools and then sampled students within the schools (Thomas \& Heck, 2001).

Because there are three enrollment categories, the HLM analyses estimate two student-level models. The multinomial logit link function expresses the log-odds of a particular type of enrollment $(m)$ relative to no enrollment, the reference category (Raudenbush \& Bryk, 2002). The multinomial student-level structural model is expressed as:

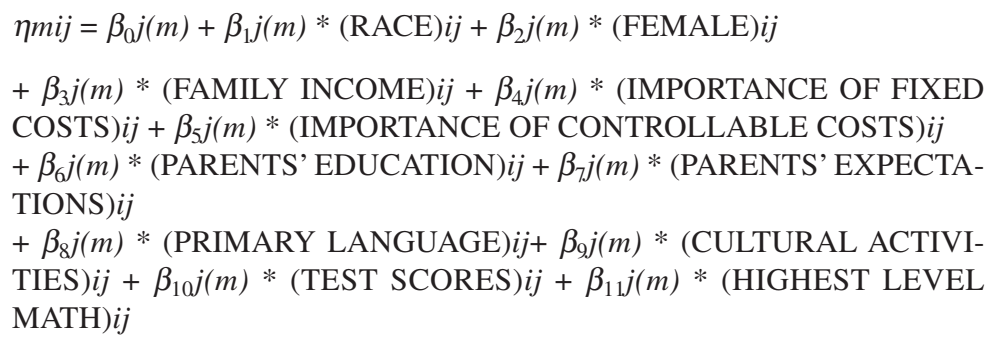




\begin{abstract}
$+\beta_{12} j(m) *($ SOCIAL CAPITAL $) i j+\beta_{13} j(m) *($ MISSING DATA $) i j$
$+\beta_{14} j(m) *($ RACE x SOCIAL CAPITAL $) i j$

where $i$ denotes the student, $j$ denotes the school, m denotes 1 to 2 types of enrollment (i.e., enrollment in a 2-year college and enrollment in a 4-year college relative to not enrolling), SOCIAL CAPITAL is a vector of parental involvement variables as described above, and RACE x SOCIAL CAPITAL represents the interactions between race/ethnicity and each of the variables in the social capital vector.
\end{abstract}

The RACE x SOCIAL CAPITAL interactions address the second research question regarding variations across racial/ethnic groups in the relationship between different types of parental involvement and the likelihood of enrolling in a two-year or four-year college.

The beta coefficients in Equation 1 characterize the distribution of college enrollment in school $j$ given observable student characteristics. In this research, only the regression coefficients for the intercept are assumed to vary across schools. In other words, the analyses constrain the coefficients for all within-school predictors to be the same for all schools (Bryk \& Raudenbush, 1992).

The school-level model takes into account the variance in the intercept across schools. The school-level model is expressed by Equation 2:

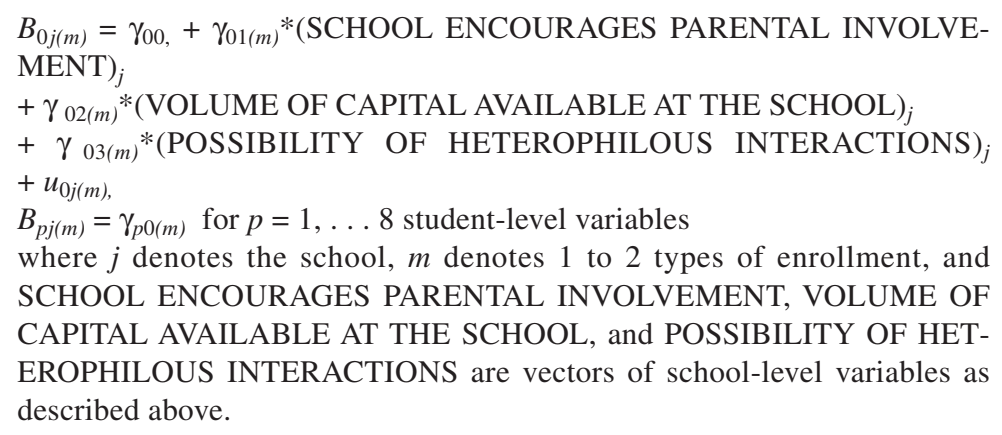

where $j$ denotes the school, $m$ denotes 1 to 2 types of enrollment, and SCHOOL ENCOURAGES PARENTAL INVOLVEMENT, VOLUME OF CAPITAL AVAILABLE AT THE SCHOOL, and POSSIBILITY OF HETEROPHILOUS INTERACTIONS are vectors of school-level variables as described above.

All student-level and school-level variables are centered on their group means since group-mean centering assumes that student-level variables are determined by both individual and school characteristics (Kreft, de Leeuw, \& Aiken, 1995). Hypothesis tests on significant parameters of variables that are aggregated up to the school level are used to determine whether contextual effects exist. In other words, because the student-level predictors are group-mean centered, hypothesis tests determine whether the statistically significant coefficients for the schoollevel variables that are measured by student-level aggregates represent contextual effects beyond the corresponding student-level effects.

The interpretation of the multinomial logit coefficients is facilitated by the use of odds-ratios. The odds-ratio represents the change in the 
odds of a particular type of enrollment relative to the reference category (not enrolled) that is associated with a one-unit change in an independent variable holding constant all other variables (Peng, So, Stage, \& St. John, 2002). An odds-ratio greater than 1 represents an increase in the likelihood of enrolling in a particular type of college or university relative to not enrolling, whereas an odds-ratio less than 1 represents a decrease in the likelihood of that type of enrollment.

\section{Limitations}

One limitation of this research is the inability to use student-level sample weights in the multilevel multinomial analysis to correct for the nonsimple random sample design (Raudenbush \& Bryk, 2002). The NELS sample design included oversampling of Hispanic and Asian/Pacific Islander students in the base year, and disproportionate retention of Hispanic, Asian/Pacific Islander, and American Indian students in the 1990 follow-up (NCES, 1994).

A second limitation pertains to the adequacy of available proxies. As noted in reviews of prior research (Dika \& Singh, 2002; Morrow, 1999), a limitation of this and other research is the reliance on proxies for parental involvement that reflect the quantity rather than the quality of interactions. Measuring the quality of interactions may be especially useful given the growing diversity of family structures (Morrow, 1999). Moreover, as Tierney (2002; Tierney \& Auerbach, in press) has argued, "family" involvement is likely a more appropriate focus than "parental" involvement, given changes over time in the definition of "family." Older siblings and members of the extended family may be a particularly important source of encouragement for minority students (Tierney \& Auerbach, in press). Nonetheless, few measures of "family" involvement are available in the NELS 1992/1994 dataset.

The study may also be limited by omitted variables, particularly with regard to measures of student financial aid (St. John, 2003). Following the example of Paulsen and St. John (2002), the analyses include measures of actual and perceived ability to pay college costs. While Paulsen and St. John (2002) also included actual college costs in their "financial aid nexus model," this study does not for several reasons. First, while Paulsen and St. John focus on both college enrollment and persistence, this study examines only college enrollment. Second, because many students in the analyses did not enroll in college after graduating from high school, at best only estimates of financial aid offers or unmet financial need could be included. Unlike other NCES datasets (e.g., National Postsecondary Student Aid Survey), the NELS includes limited, and 
only student-reported, measures of the financial aid that students receive. Thus, although including measures of family income and perceptions of college costs contributes to a comprehensive modeling of a student's habitus toward college enrollment, the exclusion of financial aid variables may result in a coefficient for family income that underestimates the relationship between family income and college enrollment (Becker, 2003).

Fourth, parental involvement is measured using data from 1992, when students in the analyses were in the 12th grade. This study focuses on the role of parental involvement in the 12th grade rather than at earlier points in time for conceptual clarity. Many other variables may intervene between the time of the involvement in 8th grade (as an example) and college enrollment after the 12th grade. Modeling the effects of parental involvement in earlier grades, the ways in which the effects of parental involvement on college enrollment change during high school, and the effects of parental involvement on other outcomes (e.g., academic preparation) are beyond the scope of this study. Because some research suggests that parental involvement declines as students move from the freshman to senior years of high school, particularly for those in college preparatory tracks (Crosnoe, 2001), this study's examination of parental involvement in the 12th grade likely produces a conservative estimate of the effect of parental involvement on college enrollment.

This research also limits measures of school structural characteristics to those that may encourage parental involvement and that describe the volume of resources that may be accessed through such involvement. Although Stanton-Salazar (1997) points to the potential roles of other structural constraints (e.g., a school's focus on bureaucratic processes), attention to a broader set of structural barriers is beyond the scope of this study.

This study is also limited by the relatively small number of students attending each school in the sample. The small number of students per school may produce samples of students that are not representative of the population of students attending the school. Nonetheless, the empirical Bayes estimating procedure employed by HLM helps address the problem of small numbers of students in each school. The small number of students per school also reduces the statistical power to detect variations across schools, resulting in conservative estimates of the schoollevel effects (Lee \& Burkum, 2003). Future research should test the relationships for the school-level variables using a dataset that includes a larger number of students per school.

Finally, because of the small numbers of African Americans and Hispanics at each high school in the NELS sample, this research cannot 
examine the ways in which variations in the characteristics of school social networks contribute to racial/ethnic group differences across high schools in the likelihood of enrolling at a 2-year or a 4-year institution. Specifically, the analyses do not converge when we allow the coefficients for race/ethnicity to vary across schools in the level-two analyses. Further research that utilizes a sample with larger numbers of African Americans and Hispanics in each high school is required to test the hypothesis, stemming from Lin's (2001b) work, that variations in the resources possessed by social networks and differences in the extent to which heterophilous interactions are possible at the school are a source of racial/ethnic group differences in college enrollment across schools.

\section{Findings}

\section{Parental Involvement is related to College Enrollment}

The multilevel multinomial analyses show that several student-level measures of parental involvement are related to the odds of enrolling in a 2-year or 4-year college in the fall after graduating from high school even after taking into account race/ethnicity, sex, and measures of economic, cultural, and human capital. A review of the statistically significant oddsratios in Table 1 shows that the odds of enrolling in either a 2-year or 4year college relative to not enrolling increase with the frequency with which the parent discusses with the student education-related topics (odds-ratio for 2-year $=1.130$; odds-ratio for 4-year $=1.164)$, contacts the school to volunteer (odds-ratio for 2-year $=1.120$; odds-ratio for 4 year $=1.143$ ), and initiates contact with school about academics (oddsratio for 2-year $=1.132$; odds-ratio for 4-year $=1.145$ ). In contrast, the odds of enrolling in either a 2-year or 4-year college decline as the frequency of parent-initiated contact with the school about behavioral issues increases (odds-ratio for 2-year $=0.849$; odds-ratio for 4-year $=0.786$ ).

A student's friends' postsecondary plans, a measure of intergenerational closure, and the ways in which parents subtly structure a student's peer group are also related to college enrollment. The share of a student's friends who plan to attend a 2-year college is positively associated with the likelihood of enrolling in a 2-year college (odds-ratio $=1.109$ ) and negatively related to the likelihood of enrolling in a 4-year college (oddsratio $=0.786$ ). The share of a student's friends who plan to attend a 4-year institution is positively related to enrollment in both a 2-year (odds-ratio $=1.164$ ) and 4-year (odds-ratio $=1.536$ ) institution, although the magnitude of the relationship is greater for 4-year than for 2-year enrollment.

After controlling for other variables, disruptions to social capital, as measured by the number of times a student's family moves, are associ- 
ated with lower odds of enrolling in either a 2 -year (odds-ratio $=0.871$ ) or 4-year (odds-ratio $=0.893$ ) college in the fall after graduating from high school relative to not enrolling.

\section{TABLE 1}

Increase in the odds of enrolling in a two-year or four-year college or university in fall 1992 relative to not enrolling that is associated with a one-unit change in each student-level and school-level variable among 1992 high school graduates (odds-ratios)

\begin{tabular}{|c|c|c|}
\hline Predictors & $\begin{array}{l}\text { Two-year } \\
\text { Enrollment }\end{array}$ & $\begin{array}{l}\text { Four-year } \\
\text { Enrollment }\end{array}$ \\
\hline \multicolumn{3}{|l|}{ Student level fixed effects } \\
\hline African American & $0.725^{*}$ & $1.598 * *$ \\
\hline Asian & 0.966 & 1.028 \\
\hline $\begin{array}{l}\text { Hispanic } \\
\quad \text { White (reference group) }\end{array}$ & 1.224 & $1.187 *$ \\
\hline $\begin{array}{l}\text { Female } \\
\quad \text { Male (reference group) }\end{array}$ & $1.146^{*}$ & $1.284 * *$ \\
\hline Family income & $1.131 * *$ & $1.126 * *$ \\
\hline College expenses and financial aid not important & $0.794 *$ & 0.877 \\
\hline $\begin{array}{l}\text { College expenses and financial aid very important } \\
\text { College expenses and aid somewhat important (referen }\end{array}$ & 0.969 & 0.965 \\
\hline $\begin{array}{l}\text { Living at home to attend college very important } \\
\text { Living at home not important (reference) }\end{array}$ & $1.561 * * *$ & 0.876 \\
\hline Parents' education & $1.211 * * *$ & $1.441 * * *$ \\
\hline Parents expect student to earn less than college degree & $0.582 * * *$ & $0.081 * * *$ \\
\hline $\begin{array}{l}\text { Parents expect student to finish college } \\
\text { Parents expect student to earn an advanced degree }\end{array}$ & 1.061 & $0.787 * *$ \\
\hline $\begin{array}{l}\text { English is primary language spoken at home } \\
\text { English not primary language spoken at home (refer }\end{array}$ & 0.892 & 0.931 \\
\hline $\begin{array}{l}\text { Participate in cultural classes } \\
\text { Do not participate (reference) }\end{array}$ & 1.030 & 1.245 \\
\hline Test score & $0.887 * *$ & $1.135 * *$ \\
\hline Took algebra 1 & $1.726 * * *$ & $2.891 * * *$ \\
\hline Took algebra 2 & $2.218 * * *$ & $9.565 * * *$ \\
\hline $\begin{array}{l}\text { Took advanced math } \\
\text { No math/missing math (reference group) }\end{array}$ & $2.288 * * *$ & $25.406 * * *$ \\
\hline \multicolumn{3}{|l|}{ Parent-student involvement } \\
\hline Parent discusses with student & $1.130 * *$ & $1.164 * * *$ \\
\hline Parent monitors behavior & 1.011 & 1.012 \\
\hline \multicolumn{3}{|l|}{ Parent-school involvement } \\
\hline Parent contacts school to volunteer & $1.120 * *$ & $1.143 * *$ \\
\hline Parent acquires info about education & 0.987 & 1.045 \\
\hline Parent knows academic requirements & 0.984 & 0.982 \\
\hline Parent-initiated contact - academics & $1.132 * *$ & $1.145^{* *}$ \\
\hline Parent-initiated contact - behavior & $0.849 * * *$ & $0.786 * * *$ \\
\hline \multicolumn{3}{|l|}{ Parent-parent involvement } \\
\hline Number parents to whom parent talks & 0.963 & 1.047 \\
\hline Friends not planning college & $0.937 *$ & 0.965 \\
\hline Friends plan 2-year college & $1.109 * *$ & $0.786^{* * *}$ \\
\hline Friends plan 4-year college & $1.164 * * *$ & $1.536 * * *$ \\
\hline
\end{tabular}


TABLE 1 (Continued)

Disruptions to involvement

Number of times family moved

Number missing items

$\begin{array}{ll}0.871 * * * & 0.893 * * \\ 0.971 * * & 0.942 * * * \\ & \\ 0.848 & 0.788 * \\ 1.068 & 1.248 * \\ 1.098 & 0.460 *\end{array}$

African American x parent discusses with student

African American x parent-initiated contact - academics

African American $\mathrm{x}$ home to attend college very import

1.068

$0.460^{*}$

School level fixed effects

School encourages involvement

School encourages parent participation

$\%$ parents volunteering in classroom

$\begin{array}{ll}1.016 & 1.022 \\ 1.095 & 1.089\end{array}$

$\%$ parents participating in PTO

0.993

1.076

Social capital available at school

Average parent discussion with student

Average parent monitoring

1.040

1.089

1.014

1.014
1.089

Average parent contacts to volunteer

1.095

$1.020 \quad 1.040$

Average parent acts to acquire info about college

1.023

Average parent-initiated contact academics

0.966

$1.214 * *$

1.113

$0.867 * *$

Average parent-initiated contact behavior

Average number friends no plan college

0.993

0.921

Average number friends plan 2-year college

Average number friends plan 4-year college

Average number parents to whom parent talks

$0.837 * * \dagger$

$0.737 * * *+$

$1.511 * * *$

$1.679 * * *$

Average number of times family moved

0.914

0.973

0.840

$0.567 * * \dagger$

Other capital available at the school

Average family income

$1.190 *$

1.104

Average parental education

Average parents expect less than a college degree

$1.285^{* *}$

$1.365 * * *+$

Average parents expect student to finish college

$0.814 * * *$

$0.651 * * *$

Average test score

1.018

1.007

0.943

1.027

$\%$ 90-91 graduates in 2-year colleges

$\%$ 90-91 graduates in 4-year colleges

$1.260 * * *$

0.961

1.030

$1.230 * * *$

Possibility of heterophilous interaction

Standard deviation family income

1.082

1.090

$\%$ African Americans grades 9-12

$0.839 *$

0.921

$\%$ Hispanics grades 9-12

$1.034 *$

1.052

Random effect (variance component of intercept) (log-odds)

Reliability of intercept

$0.375 * * * \quad 0.256 * * *$

Number of students in the analyses $\quad 9,810$

Number of schools in the analyses $\quad 1,006$

SOURCE: Analyses of NELS:92/94

NoTES: Because of space limitations, only the coefficients are presented. Standard errors are available from the authors on request. Odds-ratios based on population average estimates. College enrollment is relative to not enrolling.

$\dagger$ Per the hypothesis tests that are summarized in Table 2, the coefficient for this variable does not represent a statistically significant contextual effect above and beyond the effect for the corresponding student-level variable

$* \mathrm{p}<.05, \quad * * \mathrm{p}<.01, \quad * * * \mathrm{p}<.001$ 
The Relationship between Parental Involvement and College Enrollment Varies by Race/Ethnicity

Descriptive analyses ${ }^{2}$ show that smaller shares of African American and Hispanic than of Whites and Asian Americans enrolled in a 4-year college in the fall after graduating from high school $(38 \%$ and $30 \%$ vs. $46 \%$ and $51 \%)$. One third (32\%) of Hispanic high school graduates were enrolled in a 2-year college in October 1992, compared with about one fourth of Asian Americans (27\%) and Whites (25\%) and one fifth (21\%) of African Americans.

Table 1 shows that, after controlling for student-level and school-level variables, the odds of enrolling in a 4-year college or university are higher for African Americans (odds-ratio = 1.598) and Hispanics (oddsratio $=1.187$ ) than for Whites. These findings suggest that the lower observed 4-year college enrollment rates for African Americans and Hispanics than for Whites are explained by racial/ethnic group differences in other variables in the model. As noted by others (Hurtado, Inkelas, Briggs, \& Rhee, 1997; Perna, 2000), however, this conclusion should be interpreted with caution since only small shares of African Americans and Hispanics are comparable to Whites in terms of all other variables that are included in the model. After controlling for other student- and school-level variables, African Americans are less likely than students of other racial/ethnic groups to enroll in a 2-year college (odds-ratio = $0.725)$.

The multilevel multinomial analyses reveal two statistically significant interactions between race/ethnicity and measures of parental involvement. The odds-ratio for the interaction between African American and parental discussions is less than 1 for 4 -year (odds-ratio $=0.788$ ) enrollment. This suggests that, although the odds of enrolling in 4-year college or university generally increase with the frequency of parent-student discussions about education-related issues net of other variables (odds-ratio =1.164), the college enrollment "premium" is smaller for African Americans than for high school graduates of other racial/ethnic groups. The positive interaction between African American and parentinitiated contact with the school about academic issues on 4-year college enrollment (odds-ratio $=1.248$ ) suggests that the positive relationship between the frequency of parent-initiated contact with the school about academic issues and the odds of enrolling in a 4-year college or university (odds-ratio $=1.145$ ) is of greater magnitude for African Americans than for high school graduates of other racial/ethnic groups. The negative interaction between African American and low controllable costs on 4year enrollment (odds-ratio $=0.460$ ) suggests that, although perceptions 
of controllable costs are unrelated to enrollment in a 4-year college on average, the odds of enrolling in a 4-year institution decline as the perceived importance of low controllable costs increases among African Americans.

The Likelihood of Enrolling in College Depends on Resources That May Be Accessed Through School Social Networks

In terms of school-level effects, Table 1 shows that none of the three measures of the extent to which a school encourages parental involvement is a statistically significant predictor of college enrollment after controlling for other variables. However, the likelihood of enrolling in a 2-year or 4-year college is related to the volume of resources that may be accessed via social networks at the school. Multivariate hypothesis tests, summarized in Table 2, show that the effects of several of the schoollevel variables that are based on the average of a student-level variable represent contextual effects above and beyond the corresponding student-level effects.

TABLE 2

Multivariate hypothesis tests of the difference in the odds-ratios for school-level and student-level predictors of college enrollment among 1992 high school graduates (see Table 1)

\begin{tabular}{|c|c|c|c|c|c|}
\hline \multirow[b]{2}{*}{ Predictors } & \multicolumn{2}{|c|}{ Coefficients } & \multirow[b]{2}{*}{ Difference } & \multirow[b]{2}{*}{$\chi^{2}$} & \multirow[b]{2}{*}{$\begin{array}{c}\text { School } \\
\text { Level Effect? }\end{array}$} \\
\hline & $\begin{array}{l}\text { School- } \\
\text { Level }\end{array}$ & $\begin{array}{l}\text { Student- } \\
\text { Level }\end{array}$ & & & \\
\hline \multicolumn{6}{|l|}{ Two-Year } \\
\hline Friends not planning college & 0.837 & 0.937 & -0.100 & $15.5^{* * *}$ & No \\
\hline Friends planning 2-year college & 1.511 & 1.109 & 0.402 & $56.5^{* * *}$ & Yes \\
\hline Family income & 1.190 & 1.131 & 0.059 & $14.8 * * *$ & Yes \\
\hline Parents' education & 1.285 & 1.211 & 0.074 & $27.7 * * *$ & Yes \\
\hline Parents expect less than college & 0.814 & 0.582 & 0.232 & $51.8 * * *$ & Yes \\
\hline \multicolumn{6}{|l|}{ Four-Year } \\
\hline Parent-initiated contact-academics & 1.214 & 1.145 & 0.069 & $18.1 * * *$ & Yes \\
\hline Parent-initiated contact-behavior & 0.867 & 0.786 & 0.081 & $17.8 * * *$ & Yes \\
\hline Friends planning 2-year college & 0.737 & 0.786 & -0.049 & $62.4 * * *$ & No \\
\hline Friends planning 4-year college & 1.679 & 1.536 & 0.143 & $179.4 * * *$ & Yes \\
\hline Number of times family moved & 0.567 & 0.893 & -0.326 & $26.4 * * *$ & No \\
\hline Parents' education & 1.365 & 1.441 & -0.076 & $77.4 * * *$ & No \\
\hline Parents expect less than college & 0.651 & 0.081 & 0.570 & $326.4^{* * *}$ & Yes \\
\hline
\end{tabular}

SOURCE: Analyses of NELS:92/94

NoTES: The hypothesis tests suggest a school level effect when the difference between the school-level and student-level coefficients is statistically significant and positive.

$* \mathrm{p}<.05, \quad * * \mathrm{p}<.01, \quad * * * \mathrm{p}<.001$ 
Table 1 shows that the likelihood of enrolling in a 4-year college is positively related to the average frequency of parent-school contact about academic issues (odds-ratio $=1.214$ ) but negatively related to the average frequency of parent-school about behavioral issues (odds ratio $=$ 0.867). Students who attend high schools in which, on average, students report that most or all of their friends plan to attend a 2-year college are more likely to enroll in a 2-year college (odds-ratio $=1.511$ ), whereas students who attend high schools in which, on average, students report that most or all of their friends plan to attend a 4-year college are more likely to enroll in a 4-year college (odds-ratio $=1.679$ ) regardless of a student's own friends' plans.

Table 1 shows that the volume of other types of capital at the school attended is also related to the likelihood of enrolling in college. Students who attend high schools with high average levels of family income and parental educational attainment are more likely to enroll in a 2-year college (odds-ratio $=1.190$ and odds-ratio $=1.285$, respectively) than they are not to enroll. The likelihood of enrolling in either a 2-year or 4-year institution declines as the share of parents at the school who expect their children to earn less than a bachelor's degree increases (odds-ratios = 0.814 and 0.651 , respectively). The odds that a student will enroll in a 2year college increase with the share of the prior year's high school graduating class that enrolled in a 2 -year college (odds-ratio $=1.260$ ), whereas the odds of enrolling in a 4-year college increase with the share of the prior year's graduates that enrolled in a 4-year college (odds-ratio $=1.230)$.

The analyses suggest that the relationship between college enrollment and the possibility of heterophilous interactions depends on the measurement of the construct. Table 1 shows that the likelihood of enrolling in a 2-year college increases with the share of Hispanics in the student body (odds-ratio = 1.034) but decreases with the share of African Americans in the student body (odds-ratio $=0.839$ ).

\section{Summary}

The findings from this research shed light on each of the three research questions. First, even with a narrow definition of parental involvement (e.g., measures of parental rather than family involvement, measures of parental involvement in the 12th grade only), this research supports Coleman's (1988) conceptualization of parental involvement as a form of social capital that promotes college enrollment by conveying norms and standards. Student-level measures of parental involvement 
are related to the likelihood of enrolling in a 2-year or 4-year college relative to not enrolling, even after controlling for measures of economic capital, cultural capital, and human capital. The analyses suggest that parents convey norms and standards in ways that promote college enrollment through interactions with the student, the school, and other parents. Parent-student discussions about education-related issues are associated with a greater likelihood of enrolling in both a 2-year and a 4-year college. Parent-initiated contact with the school about volunteering and about academic matters is associated with a greater likelihood that a student will enroll at either a 2-year or a 4-year college, whereas parent-initiated contact with the school about behavioral problems is associated with a lower likelihood that a student will enroll at either a 2-year or 4-year institution relative to not enrolling. The general correspondence between a student's friends' postsecondary plans and a student's actual enrollment may reflect not only the benefits of intergenerational closure but also the ways in which parents subtly structure their child's peer group. Disruptions to the networks that are used to convey norms and standards, as measured by the number of times a student's family moved between the 8th and 12th grades, are associated with a lower likelihood of enrolling in either a 2year or 4-year college in the fall after graduating from high school.

Second, as suggested by the work of Lin (2001b) and Bourdieu (1986), the analyses reveal that the relationship between parental involvement as social capital and the likelihood of enrolling in college varies across racial/ethnic groups. Compared with students of other racial/ethnic groups, African Americans realize a smaller college enrollment premium for each unit of parent-student discussions about education-related issues but a larger college enrollment premium for each unit of parent-initiated contact with the school about academic issues. In other words, African Americans appear to be more effective than other groups at converting into college enrollment parental involvement in the form of parent-school contact about academics, but less effective than other groups at converting into college enrollment parental involvement in the form of parent-student discussions about education issues. African Americans also appear to be more sensitive than students of other groups are to controllable costs of attendance in their decision to enroll in a 4-year college.

The prevalence of different types of parental involvement also varies across racial/ethnic groups. Descriptive analyses show that African Americans average a higher level than Whites, Hispanics, and Asian Americans of parent-student discussions about education-related topics and a higher level of parent-school contact about academics. These ob- 
served differences are consistent with the notion of racial/ethnic group differences in an individual's habitus, or view of acceptable types of parental involvement (Horvat, 2001). Consistent with López and colleagues (2001), both the multilevel multinomial and descriptive analyses illustrate the need to move beyond a cultural deficit approach that focuses on defining "acceptable" behavior in terms of the behavior that is exhibited by the dominant group and to move toward an approach that appreciates the unique strengths of each group.

Third, regardless of an individual student's social, economic, cultural, and human capital, this research shows that, in support of the work by Bourdieu (1986) and Lin (2001b), the likelihood of enrolling in a 2-year or 4-year college after graduating from high school appears to be related to the volume of resources that may be accessed through social networks at the school attended. In terms of the social capital that is available at the school attended, students who attend high schools in which a high share of parents contact the school about academic matters are more likely to enroll in a 4-year college than they are not to enroll, whereas students who attend high schools in which a high share of parents contact the school about behavioral problems are less likely to enroll in a 4year college than they are to enroll. The likelihood of enrolling in a 2year college is positively related to the availability of economic capital, as measured by the average family income at the school, and cultural capital, as measured by average parental education and average parental educational expectations at the school. These school-level effects suggest that characteristics of the high school attended influence the "social distribution of possibilities," as argued by Stanton-Salazar (1997) and as manifested by college enrollment behavior.

African Americans and Hispanics not only possess fewer of the types of capital that promote college enrollment but also attend schools with fewer of the resources that promote college enrollment. Specifically, descriptive analyses show that African Americans and Hispanics not only average lower levels of family income, parental education, and math coursework than Whites and Asian Americans average but also are relatively concentrated in schools in the lowest quartiles of average family income and parental education. For example, 37\% of African Americans and $49 \%$ of Hispanics attend schools in the lowest quartile of parental education compared with 17\% of Whites and 16\% of Asian Americans. Consistent with Lin (2001b), these findings suggest that the lower observed college enrollment rates for African Americans and Hispanics are due in part to lower levels of resources that are available through the social networks at the schools they attend. 


\section{Implications for College Preparation Programs}

Although this research focused on the ways in which parental involvement in the context of a school promotes college enrollment, the results provide support for the role of programs that are designed to increase the college enrollment of African Americans and Hispanics. While the analyses suggest that such factors as family income (and thus financial aid), academic preparation, and academic achievement also influence college enrollment decisions, this study suggests that college preparation programs should focus on ways to promote the types of parental involvement that encourage both the norms and standards that are required to enroll in college and that ensure that social relationships and networks provide access to the necessary resources and opportunities. Both the levels of parental involvement for an individual student and the volume of social, cultural, and economic capital that are available through social networks are related to the likelihood that a student will enroll in college.

This research suggests that college preparation programs should recognize the ways in which the relationship between parental involvement and college enrollment varies across racial/ethnic groups. The analyses demonstrate that the return to college enrollment for two measures of parental involvement (parent-student discussions about academic issues and parent-school contact about academic issues) and one measure of economic capital (importance of living at home to attend college) is different for African Americans than for high school graduates of other racial/ethnic groups. Rather than imposing a one-size-fits-all approach, college preparation programs should view the differences across groups as an asset or form of cultural wealth that may be invested to promote college enrollment (López, Scribner, \& Mahitivanichcha, 2001; Villalpando \& Solaranzo, in press).

The results of this study also suggest that, because college enrollment is determined in part by the volume of resources that social networks possess, college preparation programs should utilize a cohort approach. Higher levels of parental involvement promote the college enrollment not only of a parent's own child but also of other students by developing the social capital that other students in the same social network may access.

The positive relationship between college enrollment and variables measuring friends' plans also suggests the benefits of a cohort approach to precollege outreach. Regardless of whether a student's friends' plans reflect intergenerational closure or the subtle influence of a parent on the composition of the peer group, the multilevel analyses show that the 
odds of enrolling in a 4-year college increase with both the student- and school-level measures of the number of friends planning to attend a 4year college and decrease with the student-level measures of the number of friends who plan to attend a 2-year college. Increasing the level of educational aspirations among the peer group may be particularly important for raising the college enrollment rates of African Americans and Hispanics. Descriptive analyses show that only 9\% of Hispanics and $12 \%$ of African Americans report that all of their friends plan to attend a 4-year institution compared with $14 \%$ of Whites and $22 \%$ of Asian Americans; they also show that only $16 \%$ of African Americans and $15 \%$ of Hispanics attend schools in the top quartile of friends planning on a 4-year college, compared with $20 \%$ of Whites and $28 \%$ of Asian Americans.

The seemingly contradictory findings from this study regarding the effects on college enrollment of the possibility of heterophilous interactions, as measured by the racial/ethnic composition of the high school attended and as described by Lin (2001b), suggest that more research is required to understand the optimal composition of the cohort. Future research should examine why the likelihood of enrolling in a 2-year college increases with the share of Hispanics in the student body but decreases with the share of African Americans and the ways in which the effects of the possibility of heterophilous interactions vary based on a student's race/ethnicity.

\section{Conclusion}

On average, African Americans and Hispanics are disadvantaged in the college enrollment process not only because of their own low levels of the types of economic, human, and cultural capital that are valued in the college enrollment process but also because of the low levels of resources that are available to promote college enrollment through the social networks at the schools they attend. This research demonstrates that parental involvement as a form of social capital is positively related to college enrollment regardless of the level of individual and school resources. In the context of structural inequities as well as social, cultural, and political challenges to efforts to increase the resources that are devoted to underrepresented groups (Oakes, Rogers, Lipton, \& Morrell, 2002), college preparation programs, particularly those that are able to effectively involve parents, offer a promising approach to addressing the continued underrepresentation of African Americans and Hispanics in higher education. 
APPENDIX A

Operational definitions of the student-level variables in the analyses

\begin{tabular}{|c|c|c|}
\hline Variable & Distribution & Source \\
\hline College enrollment & $\begin{array}{l}\text { Enrolled in a two-year college }=25.4 \% \\
\text { Enrolled in a four-year college }=43.9 \% \\
\text { Not enrolled (reference) }=30.7 \%\end{array}$ & ENRL1092 \\
\hline Race/ethnicity & $\begin{array}{l}\text { Asian }=4.5 \% \\
\text { Black }=10.4 \% \\
\text { Hispanic }=8.9 \% \\
\text { White }(\text { reference })=76.2 \%\end{array}$ & F3RACE \\
\hline Gender & $\begin{array}{l}\text { Female }=49.9 \% \\
\text { Male (reference group) }=50.1 \%\end{array}$ & \\
\hline \multicolumn{3}{|l|}{ Economic capital } \\
\hline Family income & $\begin{array}{l}\text { Mean }=10.4 \\
\text { Standard deviation }=2.43 \\
\text { Range }=1 \text { to } 15\end{array}$ & $\mathrm{~F} 2 \mathrm{P} 74$ \\
\hline $\begin{array}{l}\text { Importance of college } \\
\text { expenses and aid }\end{array}$ & $\begin{array}{l}\text { Not important }=11.1 \% \\
\text { Somewhat important (reference) } \\
=65.4 \% \\
\text { Very important }=23.5 \%\end{array}$ & $\begin{array}{l}\text { Derived from F2S59A } \\
\text { and F2S59B }\end{array}$ \\
\hline $\begin{array}{l}\text { Importance of living at } \\
\text { home for college }\end{array}$ & $\begin{array}{l}\text { Very important }=23.3 \% \\
\text { Somewhat or not important } \\
\text { (reference) }=76.7 \%\end{array}$ & $\mathrm{~F} 2 \mathrm{~S} 59 \mathrm{~F}$ \\
\hline \multicolumn{3}{|l|}{ Cultural capital } \\
\hline $\begin{array}{l}\text { Parents' educational } \\
\text { attainment }\end{array}$ & $\begin{array}{l}\text { Mean }=3.18 \\
\text { Standard deviation }=1.22 \\
\text { Range }=1 \text { to } 6\end{array}$ & F2PARED \\
\hline $\begin{array}{l}\text { Parents' educational } \\
\text { expectations for child }\end{array}$ & $\begin{array}{l}\text { Less than college degree }=18.9 \% \\
\text { College degree }=39.4 \% \\
\text { Advanced degree (reference) } \\
=41.7 \%\end{array}$ & F2P61 \\
\hline $\begin{array}{l}\text { Primary language spoken } \\
\text { at home }\end{array}$ & $\begin{array}{l}\text { English is primary language }=89.7 \% \\
\text { English is not primary language }=10.3 \%\end{array}$ & $\mathrm{~F} 2 \mathrm{P} 27$ \\
\hline $\begin{array}{l}\text { Participation in cultural } \\
\text { activities }\end{array}$ & $\begin{array}{l}\text { Participate in class at least } \\
\text { once/week }=18.2 \% \\
\text { No }=81.8 \%\end{array}$ & F2S33J \\
\hline \multicolumn{3}{|l|}{ Human capital } \\
\hline Academic achievement & $\begin{array}{l}\text { Mean }=58.61 \\
\text { Standard deviation }=18.93 \\
\text { Range }=27.9 \text { to } 99.99\end{array}$ & F22XCOMP \\
\hline Academic preparation & $\begin{array}{l}\text { Algebra I \& geometry }=14.9 \\
\text { Algebra II = 32.2 } \\
\text { At least one advanced math }=26.3 \\
\text { Other or no math (reference } \\
\text { category) }=26.6\end{array}$ & $\begin{array}{l}\text { Derived from: } \\
\text { F2RGEO_C, } \\
\text { F2RAL1_C, } \\
\text { F2RAL2_C, } \\
\text { FF2RPRE_C, } \\
\text { F2RCAL_C, } \\
\text { F2RTRI_C }\end{array}$ \\
\hline \multicolumn{3}{|l|}{ Social capital } \\
\hline $\begin{array}{l}\text { Parent-student discussions } \\
\text { about education-related } \\
\text { issues }\end{array}$ & $\begin{array}{l}\text { Mean }=0 \\
\text { Standard deviation }=1.00 \\
\text { Range }=-2.75 \text { to } 9.11\end{array}$ & $\begin{array}{l}\text { Factor composite } \\
\text { derived from: } \\
\text { F2P49A, F2P49B, } \\
\text { F2P49C, F2P49D, } \\
\text { F2P49E, F2P49F }\end{array}$ \\
\hline $\begin{array}{l}\text { Parent monitoring of } \\
\text { student behavior }\end{array}$ & $\begin{array}{l}\text { Mean }=0 \\
\text { Standard deviation }=1.00 \\
\text { Range }=-2.84 \text { to } 6.76\end{array}$ & $\begin{array}{l}\text { Factor composite } \\
\text { derived from: } \\
\text { F2P51A, F2P51B, } \\
\text { F2P51C }\end{array}$ \\
\hline
\end{tabular}




\section{APPENDIX A (Continued)}

Parent contacts school

to volunteer

Parent acquires information

about college

Parent knows academic

requirements

Parent initiates contact

with school about

academic issues

Parent initiates contact

with school about behavior

Number of parents who

whom a parent talks

Share of friends not planning college

Share of friends planning

2-year college

Share of friends planning

4-year college

Number of times family moved between 1988 and 1992
F2P44G

Mean $=0$

Standard deviation $=1.00$

Range $=-0.96$ to 6.04

Mean $=0$

Standard deviation $=1.00$

Range $=-0.59$ to 6.29

Mean $=0$

Standard deviation $=1.00$

Range $=-0.89$ to 8.88

Mean $=0$

Standard deviation $=1.00$

Range $=-0.45$ to 7.20

Mean $=3.46$

Standard deviation $=1.40$

Range $=1$ to 6

Mean $=2.13$

Standard deviation $=1.09$

Range $=1$ to 5

Mean $=2.48$

Standard deviation $=1.02$

Range $=1$ to 5

Mean $=3.46$

Factor composite

derived from:

F2P45A, F2P45B

Factor composite

derived from:

F2P46A, F2P46B

F2P46C, F2P46D

Factor composite derived from:

F2P44A, F2P44B,

F2P44C, F2P44D

Factor composite derived from: F2P44E, F2P44F

F2P55

F2S69B

F2S69D

F2S69E

Standard deviation $=1.08$

Range $=1$ to 5

Mean $=1.39$

F2S102

Standard deviation $=0.77$

Range $=1$ to 4

SouRCE: Analyses of NELS:92/94 


\begin{tabular}{|c|c|c|c|c|c|}
\hline Variable & Mean & $\begin{array}{l}\text { Standard } \\
\text { Deviation }\end{array}$ & Minimum & Maximum & Source \\
\hline $\begin{array}{l}\text { School encourages parental } \\
\text { involvement }\end{array}$ & 0 & 1.00 & -1.70 & 4.20 & $\begin{array}{l}\text { Factor derived from } \\
\text { F2C52E4, F2C52F4, } \\
\text { F2C52G4, F2C52D4, } \\
\text { F2C52C4, F2C52H4, } \\
\text { F2C52B4, F2C52A4 }\end{array}$ \\
\hline$\%$ parents who volunteer & 1.33 & 0.68 & 1.00 & 5.00 & $\mathrm{~F} 2 \mathrm{C} 54 \mathrm{~A}$ \\
\hline $\begin{array}{l}\% \text { parents who participate } \\
\text { in PTO }\end{array}$ & 1.75 & 0.95 & 1.00 & 5.00 & F2C54G \\
\hline $\begin{array}{l}\text { Average parent-child } \\
\text { discussions }\end{array}$ & 0 & 1.00 & -4.57 & 6.94 & $\begin{array}{l}\text { School-level average } \\
\text { of student-level factor }\end{array}$ \\
\hline Average parent monitoring & 0 & 1.00 & -5.18 & 1.60 & $\begin{array}{l}\text { School-level average } \\
\text { of student-level factor }\end{array}$ \\
\hline $\begin{array}{l}\text { Average parent contacts to } \\
\text { volunteer }\end{array}$ & 1.70 & 0.43 & 1.00 & 3.80 & $\begin{array}{l}\text { School-level average } \\
\text { of F2P44G }\end{array}$ \\
\hline $\begin{array}{l}\text { Average parent acts to } \\
\text { acquire info about college }\end{array}$ & 0 & 1.00 & -2.38 & 7.40 & $\begin{array}{l}\text { School-level average } \\
\text { of student-level factor }\end{array}$ \\
\hline $\begin{array}{l}\text { Average parent knows } \\
\text { academic requirements }\end{array}$ & 0 & 1.00 & -6.39 & 1.08 & $\begin{array}{l}\text { School-level average } \\
\text { of student-level factor }\end{array}$ \\
\hline $\begin{array}{l}\text { Average parent contact } \\
\text { about academics }\end{array}$ & 0 & 1.00 & -2.10 & 9.64 & $\begin{array}{l}\text { School-level average } \\
\text { of student-level factor }\end{array}$ \\
\hline $\begin{array}{l}\text { Average parent contact } \\
\text { about behavior }\end{array}$ & 0 & 1.00 & -1.16 & 9.37 & $\begin{array}{l}\text { School-level average } \\
\text { of student-level factor }\end{array}$ \\
\hline $\begin{array}{l}\text { Average \# friends no plans } \\
\text { for college }\end{array}$ & 2.11 & 0.47 & 1.00 & 5.00 & $\begin{array}{l}\text { School-level average } \\
\text { of F2S69B }\end{array}$ \\
\hline $\begin{array}{l}\text { Average \# friends plan } \\
\text { 2-year college }\end{array}$ & 2.43 & 0.54 & 1.00 & 4.00 & $\begin{array}{l}\text { School-level average } \\
\text { of F2S69D }\end{array}$ \\
\hline $\begin{array}{l}\text { Average \# friends plan } \\
\text { 4-year college }\end{array}$ & 3.50 & 0.57 & 1.00 & 5.00 & $\begin{array}{l}\text { School-level average } \\
\text { of F2S69E }\end{array}$ \\
\hline $\begin{array}{l}\text { Average number parents } \\
\text { parent talks }\end{array}$ & 3.67 & 0.61 & 1.33 & 5.75 & $\begin{array}{l}\text { School-level average } \\
\text { of F2P55 }\end{array}$ \\
\hline $\begin{array}{l}\text { Average number times } \\
\text { family moved }\end{array}$ & 1.39 & 0.34 & 1.00 & 4.00 & $\begin{array}{l}\text { School-level average } \\
\text { of F2S102 }\end{array}$ \\
\hline Average family income & 10.32 & 1.39 & 5.00 & 14.67 & $\begin{array}{l}\text { School-level average } \\
\text { of F2P74 }\end{array}$ \\
\hline Average parental education & 3.16 & 0.81 & 1.00 & 6.00 & $\begin{array}{l}\text { School-level average } \\
\text { of F2PARED }\end{array}$ \\
\hline Average English language & 87.02 & 20.29 & 0.00 & 100.0 & $\begin{array}{l}\text { School-level average } \\
\text { of F2P27 }\end{array}$ \\
\hline $\begin{array}{l}\text { Average participate in } \\
\text { cultural classes }\end{array}$ & 15.37 & 21.15 & 0.00 & 100.0 & $\begin{array}{l}\text { School-level average } \\
\text { of F2S33J }\end{array}$ \\
\hline Average test scores & 59.09 & 11.13 & 31.44 & 99.99 & $\begin{array}{l}\text { School-level average } \\
\text { of F22XCOMP }\end{array}$ \\
\hline $\begin{array}{l}\% 1991 \text { 12th graders enrolled } \\
\text { 2-year college }\end{array}$ & 2.99 & 0.91 & 1.00 & 6.00 & $\mathrm{~F} 2 \mathrm{C} 27 \mathrm{~A}$ \\
\hline $\begin{array}{l}\text { \% } 1991 \text { 12th graders enrolled } \\
\text { 4-year college }\end{array}$ & 4.24 & 1.06 & 1.00 & 6.00 & $\mathrm{~F} 2 \mathrm{C} 27 \mathrm{~B}$ \\
\hline $\begin{array}{l}\text { Standard deviation family } \\
\text { income }\end{array}$ & 1.89 & 0.83 & 0.00 & 6.61 & $\begin{array}{l}\text { Standard deviation } \\
\text { F2P74 }\end{array}$ \\
\hline $\begin{array}{l}\% \text { African Americans in the } \\
\text { school }\end{array}$ & 14.31 & 37.58 & 0.00 & 99.70 & $\mathrm{~F} 2 \mathrm{C} 22 \mathrm{C}$ \\
\hline$\%$ Hispanics in the school & 11.62 & 36.92 & 0.00 & 99.7 & $\mathrm{~F} 2 \mathrm{C} 22 \mathrm{~B}$ \\
\hline
\end{tabular}

SOURCE: Analyses of NELS:92/94 


\section{Notes}

${ }^{1}$ Because of space limitations, the factor loadings and other statistics describing the results of the factor analyses are not presented here. This information is available from the authors upon request.

${ }^{2}$ Complete results of the descriptive analyses are available from the authors upon request.

\section{References}

Adelman, C. (1999). Answers in the tool box: Academic intensity, attendance patterns, and bachelor's degree attainment. Washington, DC: U.S. Department of Education.

Becker, W. E. (2003). Omitted variables and sample selection issues in the NCES research on financial aid and college participation. Washington, DC: U.S. Department of Education, Advisory Committee on Student Financial Aid.

Bourdieu, P. (1986). The forms of capital. In J. G. Richardson (Ed.), Handbook of theory and research for the sociology of education (pp. 241-258). New York: Greenwood Press.

Bourdieu, P., \& Passeron, J. C. (1977). Reproduction in education, society, and culture. Beverly Hills, CA: Sage Publications.

Bourdieu, P., \& Wacquant, L. J. D. (1992). An invitation to reflexive sociology. Chicago: University of Chicago Press.

Bryk, A. S., \& Raudenbush, S. W. (1992). Hierarchical linear models. Thousand Oaks, CA: Sage Publications.

Cabrera, A. F., \& La Nasa, S. M. (2000). Overcoming the tasks on the path to college for America's disadvantaged. In A. F. Cabrera \& S. M. La Nasa (Eds.), Understanding the college choice of disadvantaged students (pp. 31-44). San Francisco: Jossey-Bass.

Carbonaro, W. J. (1998). A little help from my friend's parents: Intergenerational closure and educational outcomes. Sociology of Education, 71, 295-313.

Cohen, J., \& Cohen, P. (1983). Applied regression/correlation analysis for the behavioral sciences. Hillsdale, NJ: Lawrence Erlbaum Associates Publishers.

Coleman, J. S. (1988). Social capital in the creation of human capital. American Journal of Sociology, 94 (Suppl.), 95-120.

Crosnoe, R. (2001). Academic orientation and parental involvement in education during high school. Sociology of Education, 74, 210-230.

Dika, S. L., \& Singh, K. (2002). Applications of social capital in educational literature: A critical synthesis. Review of Educational Research, 72, 31-60.

DiMaggio, P., \& Mohr, J. (1985). Cultural capital, educational attainment, and marital selection. American Journal of Sociology, 90, 1231-1261.

Downey, D. B., \& Powell, B. (1993). Do children in single-parent households fare better living with same-sex parents? Journal of Marriage and Family, 55, 55-71.

Fenske, R. H., Geranios, C. A., Keller, J. E., \& Moore, D. E. (1997). Early intervention programs: Opening the door to higher education. (ASHE-ERIC Higher Education Report, Volume 25, No. 6) Washington, DC: George Washington University.

Freeman, K. (1997). Increasing African Americans' participation in higher education: African American high-school students' perspectives. Journal of Higher Education, 68, 523-550. 


\section{The Journal of Higher Education}

Fries-Britt, S. (1998). Moving beyond Black achiever isolation: Experiences of gifted Black collegians. Journal of Higher Education, 69, 556-576.

Granovetter, M. (1983). The strength of weak ties: A network theory revisited. Sociological Theory, 1, 201-233.

Hofferth, S. L., Boisjoly, J., \& Duncan, G. J. (1998). Parents' extrafamilial resources and children's school attainment. Sociology of Education, 71, 246-268.

Horn, L. J. (1998). Confronting the odds: Students at risk and the pipeline to higher education. (NCES Report No. 98-094). Washington, DC: U.S. Department of Education.

Horvat, E., Weininger, E. B., \& Lareau, A. (2003). From social ties to social capital: Class differences in the relations between schools and parent networks. American Educational Research Journal, 40, 319-351.

Horvat, E. M. (2001). Understanding equity and access in higher education: The potential contribution of Pierre Bourdieu. In J. C. Smart (Ed.), Higher education: Handbook of theory and research (Vol. 16, pp. 195-238). New York: Agathon Press.

Hossler, D., Braxton, J., \& Coopersmith, G. (1989). Understanding student college choice. In J. C. Smart (Ed.), Higher education: Handbook of theory and research (Vol. 5, pp. 231-288). New York: Agathon Press.

Hossler, D., Schmit, J., \& Vesper, N. (1999). Going to college: How social, economic, and educational factors influence the decisions students make. Baltimore: Johns Hopkins University Press.

Hurtado, S., Inkelas, K. K., Briggs, C., \& Rhee, B. S. (1997). Differences in college access and choice among racial/ethnic groups: Identifying continuing barriers. Research in Higher Education, 38, 43-75.

Kreft, I. G. G., de Leeuw, J., \& Aiken, L. S. (1995). The effect of different forms of centering in hierarchical linear models. Multivariate Behavioral Research, 30(1), 1-21.

Lamont, M., \& Lareau, A. (1988). Cultural capital: Allusions, gaps and glissandos in recent theoretical developments. Sociological Theory, 6, 153-168.

Lee, S. A. (1993). Family structure effects on student outcomes. In B. Schneider \& J. S. Coleman (Eds.), Parents, their children, and school (pp. 43-75). Boulder, CO: Westview Press.

Lee, V. E., \& Burkum, D. T. (2003). Dropping out of high school: The role of school organization and structure. American Educational Research Journal, 40, 353-393.

Lin, N. (2001a). Building a network theory of social capital. In N. Lin, K. Cook, \& R. S. Burt (Eds.), Social capital: Theory and research (pp. 3-29). New York: Aldine De Gruyter.

Lin, N. (2001b). Social capital: A theory of social structure and action. New York: Cambridge University Press.

López, G. R., Scribner, J. D., \& Mahitivanichcha, K. (2001). Redefining parental involvement: Lessons from high-performing migrant-impacted schools. American Educational Research Journal, 38, 253-288.

Mattingly, D. J., Prislin, R., McKenzie, T. L., Rodriguez, J. L., \& Kayzar, B. (2002). Evaluating evaluations: The case of parent involvement programs. Review of Educational Research, 72, 549-576.

McDonough, P. M. (1997). Choosing colleges: How social class and schools structure opportunity. Albany: State University of New York Press.

McNeal, R. B. (1999). Parental involvement as social capital: Differential effectiveness on science, achievement, truancy, and dropping out. Social Forces, 78, 117-144. 
Morrow, V. (1999). Conceptualising social capital in relation to the well-being of children and young people: A critical review. Sociological Review, 47, 744-765.

Muller, C. (1993). Parent involvement and academic achievement: An analysis of family resources available to the child. In B. Schneider \& J. S. Coleman (Eds.), Parents, their children, and school (pp. 77-113). Boulder, CO: Westview Press.

National Center for Education Statistics. (2001). Digest of education statistics: 2000. (NCES Report No. 2001-034). Washington, DC: U. S. Department of Education.

National Center for Education Statistics. (1994). National Education Longitudinal Study of 1988 second follow-up: Student component data file user's manual (NCES Report No. 94-374). Washington, DC: U.S. Department of Education.

Nettles, M. T., \& Perna, L. W. (1997). African American education data book (Vol. 1). Fairfax, VA: Frederick D. Patterson Research Institute.

Oakes, J., Rogers, J., Lipton, M., \& Morrell, E. (2002). The social construction of college access: Confronting the technical, cultural, and political barriers to low-income students of color. In W. G. Tierney \& L. S. Hagedorn (Eds.), Increasing access to college: Extending possibilities for all students (pp. 105-121). Albany, NY: SUNY Press.

Paulsen, M. B., \& St. John, E. P. (2002). Social class and college costs: Examining the financial nexus between college choice and persistence. Journal of Higher Education, 73, 189-236.

Peng, C. J., So, T.-S. H., Stage, F. K., \& St. John, E. P. (2002). The use and interpretation of logistic regression in higher education journals. Research in Higher Education, 43, 259-294.

Perna, L. W. (2000). Differences in the decision to attend college among African Americans, Hispanics, and Whites. Journal of Higher Education, 71, 117-141.

Perna, L. W. (2002). Pre-college outreach programs: Characteristics of programs serving historically underrepresented groups of students. Journal of College Student Development, 43, 64-83.

Portes, A. (1998). Social capital: Its origins and applications in modern sociology. Annual Review of Sociology, 24, 1-24.

Qian, Z., \& Blair, S. L. (1999). Racial/ethnic differences in educational aspirations of high school seniors. Sociological Perspectives, 42, 605-625.

Raudenbush, S., \& Bryk, A. (2002). Hierarchical linear models: Applications and data analysis methods, 2nd edition. Thousand Oaks, CA: Sage Publications.

St. John, E. P. (1991). What really influences minority attendance? Sequential analysis of the High School and Beyond sophomore cohort. Research in Higher Education, 32, 141-158.

St. John, E. P. (2003). Refinancing the college dream: Access, equal opportunity, and justice for taxpayers. Baltimore: Johns Hopkins University Press.

Snijders, T., \& Bosker, R. (1999). Multilevel analysis: An introduction to basic and advanced multilevel modeling. Thousand Oaks, CA: Sage Publications.

Stanton-Salazar, R. D. (1997). A social capital framework for understanding the socialization of racial minority children and youth. Harvard Educational Review, 67, 1-40.

Stanton-Salazar, R. D., \& Dornbusch, S. M. (1995). Social capital and the reproduction of inequality: Information networks among Mexican-origin high school students. Sociology of Education, 68, 116-135.

Stevenson, D. L., Schiller, K. S., \& Schneider, B. (1994). Sequences of opportunities for learning. Sociology of Education, 67, 184-198. 


\section{The Journal of Higher Education}

Sui-Chu, E. H., \& Willms, J. D. (1996). Effects of parental involvement on eighth-grade achievement. Sociology of Education, 69, 126-141.

Swail, W. S., \& Perna, L. W. (2000). A view of the landscape: Results of the national survey of outreach programs. In College Board, Outreach program handbook 2001 (pp. xi-xxix). New York: The College Board.

Thomas, S. L., \& Heck, R. H. (2001). Analysis of large-scale secondary data in higher education research: Potential perils associated with complex sampling designs. Research in Higher Education, 42, 517-540.

Tierney, W. G. (2002). Parents and families in precollege preparation: The lack of connection between research and practice. Educational Policy, 16, 588-606.

Tierney, W. G., \& Auerbach, S. (in press). Toward developing an untapped resource: The role of families in college preparation. In W. G. Tierney (Ed.), Nine propositions relating to the effectiveness of early intervention programs.

Villalpando, O., \& Solaranzo, D. (in press). The role of culture in college programs: A review of the research literature. In W. G. Tierney (Ed.), Nine propositions relating to the effectiveness of early intervention programs.

Zick, C. D., Bryant, W. K., \& Osterbacka, E. (2001). Mothers' employment, parental involvement, and the implications for intermediate child outcomes. Social Science Research, 30, 25-49. 